New

\title{
Game Theory in the Social Sciences
}

\section{Concepts and Solutions}

by Martin Shubik

Written by a world-recognized authority on game theory and its applications, Game Theory in the Social Sciences presents the subject in a clear, concise, and self-contained fashion. It proceeds from fundamental concepts and applications to general economic theory to the development of models and solutions that describe aspects of human societies. The book is unique in its broad coverage, concentration on model building, and overview of applications to many disciplines.

524 pp. $\$ 35.00$

\section{Habermas}

\section{Critical Debates}

\section{edited by John B. Thompson and David Held}

The essays in this book, all of them published here for the first time, provide a long-overdue critical discussion of Jürgen Habermas's ideas. They include: Habermas and Marxism, Agnes Heller; Habermas's Concept of Critical Theory, Rüdiger Bubner; Habermas's 'Overcoming' of Hermeneutics, Thomas McCarthy; Cognitive Interests and Self-Reflection, Henning Ottmann; Sci-' ence and Objectivity, Mary Hesse; Universal Pragmatics, John B. Thompson; Habermas and Practical Reason, Steven Lukes; Labour and Interaction, Anthony Giddens; Habermas's Theory of Social Evolution, Michael Schmid; Crisis Tendencies, Legitimation and the State, David Held; Critical Sociology and Authoritarian State Socialism, Andrew Arato; and Reply to my Critics, Jürgen Habermas.

336 pp. $\$ 30.00$ cloth, $\$ 12.50$ paper

(Credit card orders accepted by phone: 617-253-2884)

28 Carleton Street, Cambridge, MA 02142 


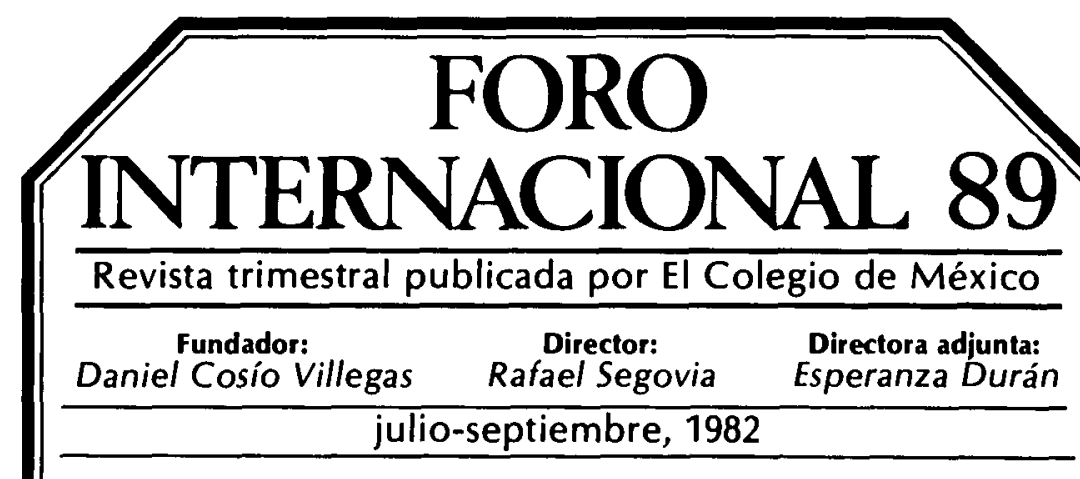

\section{Artículos}

Sudáfrica o "Azania": Reflexiones sobre un pais en disputa

Wayne A. Selcher,

Dilemas de política en las relaciones de Brasil con Africa: ejemplo de obstáculos en las relaciones Sur-Sur

Wolf Grabendorff,

Las relaciones entre América Latina y Europa Occidental: Actores

nacionales y transnacionales, objetivos y expectativas

Allan Angell,

Maoistas de salón de clase: la política de los maestros bajo el gobierno militar peruano

\section{Comentario}

Miguel S. Wionczek,

Reflexiones sobre las limitaciones de la política energética de México

Adjunto giro bancario o cheque núm. del banco

por la cantidad de

a la orden de El Colegio de México, A.C., importe de mi suscripción por año (s) a la revista Foro Internacional.

Nombre Tel.

Dirección

Código Postal

Estado Ciudad País

Suscripción anual en México: $\$ 425.00$ M.N.

E.U., Canadá, centro y sur de América: $\$ 25.00$ U.S. Dls. Resto del mundo: $\$ 34.00$ U.S. Dls.

Favor de enviar este cupón a El Colegio de México, Departamento de Publicaciones, Camino al Ajusco 20, 10740 México, D.F. 


\section{Journal of Peace Research}

An interdisciplinary journal of scientific reports in the field of peace research. Edited quarterly at the International Peace Research Institute, Rådhusgt. 4, Oslo 1, Norway

JPR has its main focus on research on direct and structural violence, conflict theory, and theoretical debates.

The 1981 volume included two special issues

\section{Causes of War, including}

J. David Singer: Accounting for International War

Klaus Jürgen Gantzel: Another Approach to a Theory on the Causes of International War Peter Wallensteen: Incompatibility, Confrontation, and War

\section{Theories of Peace, including}

Hảkan Wiberg: What have we learnt about Peace 1964-1980
Johan Galtung: Social Cosmology and the Concept of Peace

Other topics 1981-82

Gert Krell: Capitalism and Armaments Walter Goldstein: The Opportunity Cost of Acting as a Super Power

Samuel S. Kim: The Sino-American Collabo. ration and Cold War II

Miroslav Nincic: Understanding International Conflict

For the 1982 volume two special issues are being prepared

Current Events in Poland Alternative Defense Conceptions

\section{ORDER FORM - - - - - - - - - - - - - - - - $----\geq>$}

\section{Journal of Peace Research}

Published quarterly

ISSN 0022-3433

Please enter my one-year subscription as indicated below

Rates 1982

$\square$ Institutions - NOK 155,-/US\$ $28 \quad \square$ Individuals - NOK 132,-/USS 24

Postage included. Air freight to the USA and Canada at no extra cost

Prices are subject to change without notice

Name:

Address:

Individuals must order direct from the publisher

Cheque enclosed $\square$ Please send invoice

Please return your order to: UNIVERSITETSFORLAGET

Subscription department, P.O.Box 2959 Tøyen, Oslo 6, Norway

US. Office: P.O.Box 258, Irvington-on-Hudson, NY 10533, USA 


\section{LO SPETTATORE INTERNAZIONALE}

A quarterly journal of the Istituto Affari Internazionali Viale Mazzini 88 - 00195 Rome (Italy)

Editor: Gianni Bonvicini - Asst. Editor: Diane Cherney

VOLUME XVII NUMBER 1 JANUARY-MARCH 1982

Nicola Acocella and Roberto Schiattarella, Italian Direct Investment in Developing Countries

Carlo Boffito, Factors Orienting Recent Soviet Foreign Policy on Raw Materials

Paolo Guerrieri, Multinational Corporations and the Mining Industry

Annual Report: Activities in 1981

Annual Subscription: Italy Lit. 15,000; Elsewhere Lit. 20,000. Orders should be sent directly to the publisher: Società Editrice "ll Mulino»-Via S. Stefano 6-40125 Bologna (Italy).

\section{Journal of Common Market Studles Founding Editor: UWE KITZINGER Edited by LOUKAS TSOUKALIS}

This inter-disciplinary journal publishes articles which provide an in-depth analysis of important current issues by academics and policy-makers.

Although the main focus of the Journal has been the study of European integration, many articles are published on experiments in integration throughout the international system, including Latin America, Eastern Europe, the Arab World, Asia and Africa. The Journal of Common Market Studies is published quarterly in association with the University Association for Contemporary European Studies.

Annual Subscription:

Institutions: E22.00 (UK) E27.00/overseas) \$56.00/USA \$67.25 (Canada) Individuals: E15.00 (UK) E18.50 (overseas) \$42.50 (USA) \$5I.00 (Canada) Orders to Journals Department.

108 Cowley Road, Oxford. OX4 IJF, England

Published by BASIL BLACKWELL, Oxford England 


\section{"The Art and Science of Negotiation is one of the most important books ever published on the subject. I learned more about negotiation from reading this book than I have from reading everything else on the topic." \\ - Lawrence Susskind, Massachusetts Institute of Technology}

An essential tool for serious negotiators looking to improve their performance, Raiffa's book blends shrewd analysis with a touch of art. An expert look at the subject.

Drawn from experiences over 25 years as a professor at Harvard Business School and Kennedy School of Government, and as founder and first director of the International Institute of Applied Systems Analysis, this sophisticated new book surpasses other negotiation books, stressing analysis as well as psychology.

Achieve ethical results.

Emphasizing the need for joint problem solving to achieve results benefiting all parties, Raiffa offers a rational, creative approach to settling disputes.

"Howard Raiffa's clear exposition, keen analysis, and wealth of illustration go far toward providing a feeling for the art and an understanding of the science of negotiation. His insights into the ethical dilemmas confronted by the responsible negotiator are especially valuable.'

- Elliot L. Richardson

\section{The Art and Science of Negotiation}

How to resolve conflicts and get the best out of bargaining.

\section{Howard Raiffa}

448 pages $\$ 18.50$

The Belknap Press of

Harvard University Press

Cambridge, Massachusetts 02138 


\section{The Jerusalem Journal of International Relations}

THE LEONARD DAVIS INSTITUTE

FOR INTERNATIONAL RELATIONS

THE HEBREW UNIVERSITY OF JERUSALEM

The Jerusalem Journal of International Relations is a quarterly dealing with key issues in the study of international politics and reflecting the global significance of the Middle East. Included are works by internationally recognized scholars writing both on central questions of policy and on theoretical issues relating to the evolving international system.

Among the articles in Volume 5 are:

"Reflections on Détente," Abba Eban

"The Future of Détente," John Steinbruner

"Detente, Israel and the Middle East," Simcha Dinitz

"The Frailty of Complex Interdependence: A Worst-Case Scenario for the 1980s," Ernst B. Haas

"The Soviet Nuclear Threat Towards the Close of the Yom Kippur War," Yona Bandmann and Yishai Cordova

"Computer-Based Decision Analysis: An Application to a Middle East Evacuation Problem," Clinton W. Kelly, III, Stephen J. Andriole and Judith Ayres Daly

"Avoiding War and Avoiding Peace: The Dubious Internal Legitimacy of Self-Restraint," Davis B. Bobrow

Editor: Gabriel Sheffer

Subscriptions: US $\$ 25$ per volume

Distribution by: The Magnes Press, The Hebrew University, 91904 Jerusalem, Israel 


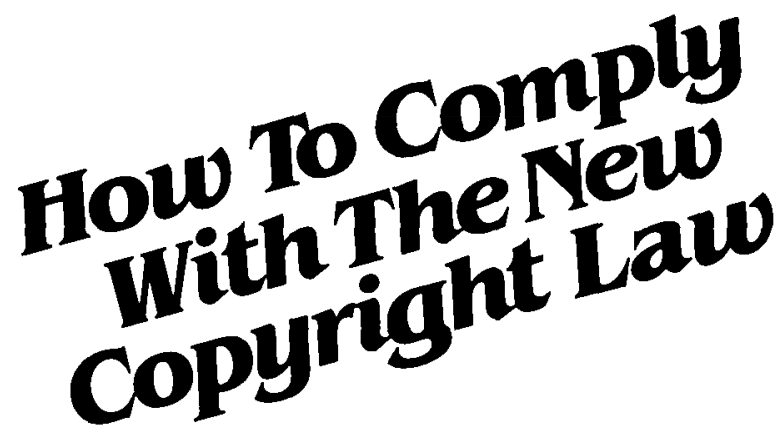

Libraries everywhere have found the easy way to fill photocopy requests legally and instantly, without the need to seek permissions, from this and over 3000 other key publications in business, science, humanities, and social science.

Participation in the Copyright Clearance Center (CCC) assures you of legal photocopying at the moment of need. You can:

Fill requests for multiple copies, interlibrary loan (beyond the CONTU guidelines), and reserve desk without fear of copyright intringement.

Supply copies simply and easily trom registered publications. The CCC's flexible reporting system accepts photocopying reports and returns an itemized invoice. You need not keep any records, our computer will do it for you.

The Copyright Clearance Center is your one-stop place for on-the-spot clearance to photocopy for internal use. You will never have to decline a photocopy request or wonder about compliance with the law for any publication registered with the CCC.

For more information, iust contact:

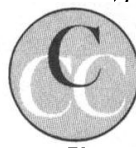

Copyright Clearance Center

21 Congress Sireet

Salem, Massachusetts 01970

(617) $744-3350$

a not-tor-profit corporation

the best explanation of what the UN is, and its aims and achievements.

The Chronicle is designed for everyone learning or teaching about the United Nations.

\section{Each monthly issue of UN Chronicle contains:}

- Record of Nows

- Articles by distinguished contributors on various aspects of United Nations work in all parts of the world.

- Notes of the month, including announcements of international

Annual subscription meetings, book reviews and selected documentation.

- Descriptions of conventions and agreements.

- Illustrations devoted to a pictorial coverage of events, people and places.

$\$ 14.00$

\section{UNITED NATIONS}

Room A-3315

New York. N.Y. 10017

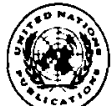

PUBLICATIONS

Palais des Nations

1211 Geneva 10, Switzerland 


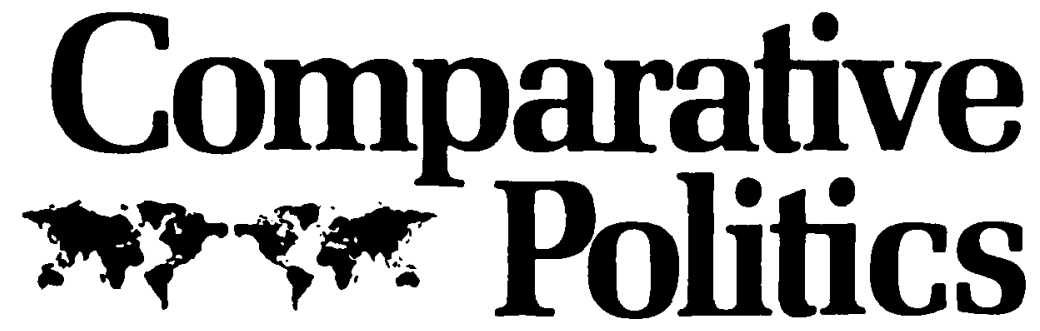

Editor-in-Chief: Dankwart A. Rustow

(City University of New York)

Comparative Politics is an international journal containing articles devoted to comparative analysis of political institutions and behavior. Articles range from political patterns of emerging nations to contrasts in the structure of established societies. Comparative Politics communicates new ideas and research findings to social scientists, scholars, and students. The journal is indispensable to experts in research organizations, foundations, consulates, and embassies throughout the world.

Volume 14 Number 3 April 1982

1968-79-Feminism and the Italian Party System: Women's Politics in a Decade of Turmoil Yasmine Ergas

The Labor Movement in Spain: From Authoritarianism to Democracy Robert M. Fishman

Leninists and Political Inequalities:

The Nonrevolutionary Politics of Communist States

Daniel N. Nelson

Dual Authority Polities Dan Horowitz

Published four times a year. Founded 1968.

Subscription rates: Individuals $\$ 15 / 1$ yr., $\$ 28 / 2$ уг., $\$ 40 / 3$ yг.; Institutions $\$ 25 / 1$ yr.. $\$ 50 / 2$ yr.. \$75/3 yr.; Students $\$ 8 / 1$ yr.; Outside the U.S.A.: Add \$3/yr.; Airmail: Add \$12/yr.; Single copies \$5/individuals, \$7/institutions.

ISSN 0010-4159.

Please address inquiries and orders to:
Transaction Periodicals Consortium Department TA 2000 Rutgers-The State University New Brunswick, NJ 08903 


\section{International Organization}

A journal of political and economic affairs

\section{Articles}

Capitalism and hegemony:

David D. Laitin

Yorubaland and the

international economy

Exchange rate system, policy

Bruce E. Moon

distortions, and the

maintenance of trade dependence

Intergovernmentalism in the

Paul Taylor

European Communities in the

1970s: patterns and perspectives

Trade politics in the

Third World: a case study of

the Mexican GATT decision

\section{Research note}

Technology transfer patterns and

Devora Grynspan industrialization in LDCs: a study of licensing in Costa Rica 